9. Тыхеева Ю.Ц. Человек в городском пространстве: Философско-антропологические основания урбанологии : дис. ... д-ра филос. наук: 09.00.13; [Место защиты: Санкт-Петербургский гос. ун-т]. СПб., 2004.

10. Чичканова Т.А. Пространство города как предмет педагогического исследования (к постановке проблемы) // Интернет-журнал «Науковедение». 2014. № 4 (23). URL: https://cyberleninka.ru/article/n/prostranstvo-goroda-kak-predmet-pedagogicheskogo-issledovaniya-k-postanovke-problemy (дата обращения 29.04.2019).

\section{Elena Teplova,}

PhD in History, Associate Professor, Department of Cultural Studies; Deputy Director, Center for Historical and Cultural Studies of Religion and Intercivilizational Relations, Institute of Social Studies and Humanities, Moscow Pedagogical State University (Moscow),

\section{tef-mioo@mail.ru}

\section{Childhood in the city of the 1950-1980s: the yard as a space of socialization}

Soviet childhood is an extensive topic possessing a powerful discussion potential. In the period from the 1950s to the end of the 1980s, the city space, where a significant part of a child's life took place, along with school, social organizations and family, was an important institution for socialization. The yard was a place of childhood, where the development of basic communication skills was carried out. This process is reflected both in Soviet cinema and modern literature.

Keywords: anthropology of Sovietness, socialization, Soviet childhood, school space, Soviet school everyday life, Ethnography of childhood, history of pedagogy, urban everyday life, urban environment, city yard, life skills, children and teenagers

\section{Марина Латышева}

\section{Образ советской женщины в журнале «Работница» (1923-1937 гг.)}

Задача данного исследования - анализ репрезентации женщин-рабочих в официальной советской прессе. В качестве источника автором избран журнал «Работница» - на ряду с «Крестьянкой» ключевой женский журнал исследуемого периода. Двойствен ность положения женщины в Советском Союзе, при котором она должна была быть и работницей, и общественницей, и политическим актором, и оставаться при этом матерью и женой, нашла свое отражение на страницах советских женских журналов. В исследовании анализируется, как именно государственная риторика в отношении женщин, смена точки зрения власти в разные моменты времени отражались в официальной прессе.

Ключевые слова: антропология советскости, гендерные исследования, журнал «Работница», советская женщина, женщина на производстве

В последние годы в России стал особенно заметен интерес к советской истории и советскому прошлому. Очевидно, что общество пытается таким образом определить свое отношение к происходившему в тот период, преодолеть полученные травмы поколений, увидеть параллели с сегодняшним днем и найти решение современных проблем и трудностей. Задача публичной истории как нового междисциплинарного направления исторической науки заключается в том, что она может помочь обществу лучше узнать свою историю, принять травматические ситуации и предостеречь от по-

Латышева Марина Сергеевна, историк, магистр ВШЭ (Москва),mss152204@ universitas.ru вторения возможных ошибок.

Нашим современникам также интересна и частная жизнь предыдущих 
поколений, история повседневности, в том числе ее гендерный аспект. В XX веке российским женщинам пришлось пережить невероятные потрясения. Начиная с революционных преобразований, когда был сломан весь уклад патриархальной жизни, через трудные военные годы к очередным потрясениям 1990-х гг., когда женщинам снова пришлось подстраиваться под новые реалии.

В разные исторические моменты государству были необходимы разные социальные женские роли. Конечно, до середины XIX века главным предназначением женщины считались замужество и материнство. Однако с развитием техники, производства и началом индустриализации меняется и социальная роль женщины. Она становится более активным членом общества, начинает работать не только домашней прислугой, но и приходит на фабрики и заводы. Постепенно у женщин появляется несколько социальных ролей, которые они могут выбрать. При этом государство имеет определенные возможности для укрепления в обществе того или иного женского образа. Для этой цели обычно используются средства массовой информации. В Советском Союзе это были, прежде всего, газеты, журналы, позднее - радио и телевидение.

Задача данного исследования - анализ репрезентации женщин-рабочих в официальной советской прессе. Известно, что большевики при создании нового государства предполагали также и создание единого мирового коммунистического сообщества, и создание нового типа человека. При этом они, с одной стороны, не учитывали гендерные различия у людей будущего, однако с другой - чаще всего под определением «человек» подразумевался «мужчина». В качестве примера можно привести статьи А.К. Гастева, А.В. Луначарского, А.П. Платонова $[17 ; 28 ; 32]$. Вместе с тем большевики не могли обойти вниманием решение женского вопроса. Они предполагали предоставить женщинам гражданские права и свободы, сделать их активными членами общества, установить равноправие полов. Однако в силу социальных, экономических и психологических причин этого не удалось сделать. Л. Эттвуд напоминает, что Советский Союз не был единственным государством, которое столкнулось со смешением гендерных ролей в результате индустриальной революции [63, p. 2].

Причины этого рассматривает в своей работе «Линзы гендера» Сандра Бэм, рассуждая о природе андроцентризма нашего мира. Андроцентризм подразумевает не только тот факт, что власть принадлежит мужчинам, но и определяет, как эта власть оказывается представленной в обществе с помощью «культурных и психологических механизмов» $[11$, с. 79]. Нельзя говорить о том, что такая система не дает женщинам развиваться. Женщина может многого достичь в мужском мире, но только в тех областях, где мужчины не препятствуют ее продвижению, и до тех пор, пока она согласна с абсолютной властью мужчин. Похожая ситуация сложилась с решением женского вопроса и в Советской России. Революционеры предоставили женщинам гражданские права и свободы, дали право распоряжаться своим браком и репродуктивной функцией, однако как только излишняя свобода женщин стала невыгодной государству с экономической точки зрения, риторика мужчин изменилась - «товарищи по оружию отправили их на кухню» $[11$, с. 78$]$.

Двойственность положения женщины в Советском Союзе, при котором она должна была быть и работницей, и общественницей, и политическим актором, и оставаться при этом матерью и женой, нашла свое отражение на страницах советских женских журналов. 
В своем исследовании мне бы хотелось рассмотреть именно эту проблему: как именно государственная риторика в отношении женщин, смена точки зрения власти в разные моменты времени отражались в официальной прессе.

Журнал «Работница» был наряду с «Крестьянкой» одним из главных журналов страны, созданных для женщин. Редакция журнала предоставляла женщинам необходимые сведения о текущей ситуации в стране, о событиях за рубежом, а также публиковала небольшое количество развлекательного материала. Одновременно с этим все материалы транслировали читателям образ современной им женщины. Естественно, что в «Работнице» был прежде всего представлен образ женщины рабочей специальности.

Репрезентация этого образа на страницах журнала осуществлялась через рассказ о жизни женщины в разных социальных ситуациях. Журнал позволяет нам увидеть женщину-работницу и общественницу, и мать, и домашнюю хозяйку. В силу специфики исторического момента не все эти роли были распределены в судьбе женщины равномерно. Например, на работу приходилась большая часть жизни советской женщины, в меньшей степени она предстает перед нами рачительной хозяйкой и женой.

Революция принесла в страну массу радикальных изменений, не все из которых можно было бы назвать приятными. Однако официальное признание Международного женского дня в качестве праздника и организация торжественных встреч и вечеров в его честь нашли горячую поддержку и одобрение среди работающих женщин. В «Работнице» как главном печатном органе Женотдела и ключевом советском журнале для женщин обязательно появлялось официальное поздравление для работниц Советского Союза. Следовательно, можно предположить, что журнальные передовицы, выпущенные к мартовскому празднику, наиболее ярко отразят роль и место женщины-рабочего в новом обществе, покажут, насколько важна работа женщин, сколько ими уже сделано, и как им следует развиваться дальше. Однако при изучении поздравительных номеров журнала оказалось, что это не совсем так.

В 1923 г. поздравление с Международным женским днем в журнале не вышло вовсе. Во всем номере этой теме была посвящена лишь одна маленькая заметка: «в ознаменование 8 марта» «Московский отдел народного образования предоставил... 50 мест в детских учреждениях для детей работниц вдов» [24]. Зато в следующем, апрельском, номере появились описания праздничных мероприятий, полученные от рабкоров или корреспондентов журнала. Интересно, что в двух заметках работницы сетуют на то, что праздник «не установлен декретом» [33] и не является «общим красным числом» [16]. Более того, они сравнивают новый светский праздник с церковным, описывают его как «светлый праздник раньше» [16, с. 3], предлагают «изменить на Николу или... другого какого святого» $[24$, с. 2]. Этот факт вполне может свидетельствовать о силе старых привычек и еще не перестроившемся на советский лад сознании женщин.

В 1924 г. ситуация с поздравлениями в журнале меняется, уже один из февральских номеров был посвящен женскому празднику. В качестве поздравления в журнале была дана перепечатка статьи В.И. Ленина [30]. Впервые статья была издана в приложении №51 к газете «Правда» от 8 марта 1921 г. под псевдонимом «Н. Ленин». В те дни страна скорбела о смерти любимого вождя, и напоминание его слов на страницах «Работницы» выглядело органично. Кроме этого, в номере было размещено поздравление от Клары Цеткин [57], 
а также фоторепортажи с праздничных демонстраций в разных городах Советского Союза [25].

Оба поздравительные текста, В.И. Ленина и К. Цеткин, наполнены революционной тематикой и восхищением молодой советской страной, которой удалось «низвергнуть капитализм» [57] и начать «строительство нового общества» $[30$, с. 2]. Ленин упоминает борьбу за равноправие полов и утверждает, что «от неравенства женщины с мужчиной по закону... у нас... не осталось и следа» [30]. Оба автора призывают оставить в прошлом «домашнее рабство» и перейти к «крупному, обобществленному хозяйству» [30], организовать работу по охране материнства. Все это позволит женщине стать свободной, даст возможность «развиваться и работать по мере ее дарований» $[57$, с. 5].

Контент-анализ данных текстов показал, что в них нет отдельного упоминания женщин-рабочих, также, как и вообще какого-либо упоминания профессий. Оба автора говорят о женщинах в целом, об их угнетенном положении и высказывают надежду на то, что вскоре все женщины станут по-настоящему свободными, смогут работать на благо советской страны и мирового коммунистического движения.

Начиная с 1925 года поздравления с Международным женским днем становятся обязательным атрибутом одного или нескольких весенних номеров. В 1925 г. уже в февральском номере выходит статья заведующей женотделом ЦК РКП(б) А.В. Артюхиной «Как готовиться к 8 марта» [3, с. 1-2], где автор отмечает, что перед празднованием женского дня необходимо проверить, все ли сделано для «раскрепощения трудящихся женщин», достаточно ли открыто столовых и яслей, активно ли работают профсоюзы и делегатки. Кроме того, А.В. Артюхина призывает не забывать о женах рабочих, домашних работницах и безработных женщи- нах, предлагает привлекать их к подготовительной работе для организации торжественного вечера и пользоваться их помощью во время проведения праздника. Отдельно автор отмечает необходимость работы с крестьянками, говорит о необходимости поездок работниц в деревню для организации практической помощи деревенским жителям [3, с. 2].

В мартовском номере 1925 г. были опубликованы два поздравления, от советского профсоюзного лидера Клавдии Николаевой [36, с. 2] и Клары Цеткин [56]. В поздравительных текстах по-прежнему сохраняется тема революции, призывы к борьбе с «мировой буржуазией». Николаева называет сознательных работниц «основой партии», убеждает их работать с «отстающими» женщинами, дабы те смогли занять активную общественную позицию и начать «борьбу за укрепление диктатуры пролетариата» [36, с. 2].

В 1926 г. на обложке журнала появляется лозунг: «8 марта - день смотра боевых сил работниц и крестьянок всех стран» (04/1926 - здесь и далее номера журнала «Работница» указаны в формате номер/год). Интересно, что его же мы встретим и гораздо позже, в мартовском номере журнала за 1937 год [35, с. 3].

Во второй половине 1920-х - начале 1930-х гг. революционная риторика праздничных выпусков меняется на хозяйственную и бытовую, но остается такой же боевой. Теперь женщин в их праздничный день призывают к борьбе за освобождение от домашних дел, повышение грамотности и культуры поведения. Главный редактор журнала $\Phi$. Нюрина убеждает женщин «удесятерить свою силу за переустройство быта», изменить свою обыденную жизнь «для борьбы с пьянством, матерщиной, грязью» [37, с. 3].

Как видно по отдельным публикациям в журнале, сами женщины поддерживали эти лозунги, стремились 
сделать свою жизнь лучше, убрать и украсить свою комнату, содержать дом в чистоте. Например, участницы здравячейки (ячейка здоровья, составленная из рабочих предприятия или жителей дома, призванная следить за санитарно-гигиеническим состоянием жилья, детских учреждений, столовых и т. д.) одного из московских домоуправлений организовали в подшефных им домах субботники чистоты. Было принято решение «следить за санитарным состоянием жилищ в течение круглого года» [12, с. 28]. Получить звание показательного общежития обещают в канун праздника 8 марта 1933 г. и работницы Донбасса, чье образцовое общежитие уже премировали «пятью музыкальными инструментами и библиотекой» [55, с. 15].

В годы первых пятилеток в номерах журнала, посвященных весеннему празднику, появились общие обзорные статьи о работе женщин. В них работницы обещали выполнить и перевыполнить план, работать быстро, аккуратно, не делать брака, поддерживать решения партии $[5 ; 48 ; 53]$. Однако таких статей было немного.

Таким образом, журнал не ставил своей задачей особо выделить женщин-рабочих в поздравлениях к Международному женскому дню. В течение 1920-х гг. в мартовских передовицах сохраняется упоминание революционной борьбы и милитаристская риторика: адресатов сравнивают с воинами, ведущими трудный бой за освобождение женщин во всем мире и укрепление позиций международного коммунистического движения. В начале 1930-х гг. революционные призывы отходят на второй план, но женщин вновь зовут на битву - с домашним бытом, неграмотностью, невоспитанностью. Кроме того, женщины-рабочие теперь воюют на трудовом фронте, сражаясь за выполнение пятилетнего плана.
Итак, изначальное предположение о том, что изучение заглавных статей журнала, выпущенных к Международному женскому дню, презентует читателям канонический образ рабочей женщины, не подтвердилось. В данных статьях работницы никак не выделяются из остальной массы женщин, к которым обращены поздравления. Жительницы страны Советов считаются передовым отрядом мировой революции, который должен быть примером и обязан советом и делом помогать женщинам капиталистических стран в их борьбе за свои права. Дома же советские женщины должны быть достойны этого звания, бороться с отдельными бытовыми недостатками, заниматься самообразованием, работать лучше остальных.

Анализ статей к мартовскому празднику за несколько лет показывает, что они обращены к активной самостоятельной женщине, которая может не только отстоять свои права и решить собственные проблемы, но и готова помогать тем, кто слабее ее, кто пока не достиг нужного уровня коммунистической сознательности. Именно такую женщину представляет журнал на своих страницах, показывая ее в разных социальных ролях.

Начиная с 1924 г. в журнале появляются подробные биографии работниц. В них корреспонденты рассказывают о трудной судьбе женщин, о том, как изменилась их жизнь после революции. Постепенно из этих рассказов складывается общая история поколения работниц, чья молодость пришлась на годы революций и гражданской войны. Канва этих историй безыскусна: трудное детство или сиротство, очень раннее начало работы в качестве прислуги или няньки, изредка чернорабочей, несчастливое замужество (муж - пьяница и грубиян) или ранняя смерть мужа, рождение и частая потеря детей, воспитание их в такой же нищете и сиротстве, в какой выросла мать. Многие женщины 
в такой ситуации воспринимали революцию с благодарностью, с надеждой на лучшую долю. Многие пишут о том, что они «увидели свет» только после Октября.

В Советской России у женщины появилась возможность работать, получать зарплату, стать самостоятельной. Кроме того, теперь она могла участвовать в социальной и политической жизни страны, пойти в школу ликвидации безграмотности, быть избранной делегаткой от своего предприятия или района, ходить на встречи, заседания, торжественные мероприятия. Все это стало для женщин новым, неожиданным, но, по всей вероятности, полезным опытом.

Одна из работниц гордится тем, что «справлялась со своей работой», хотя у нее было четверо детей, и она признается, что делегатские собрания были для нее отдыхом [27]. Ей вторит другая корреспондентка, также ставшая делегаткой: большая семья не позволяет ей «всецело отдаться общественной работе», но она надеется, что и ее работа приносит пользу [26]. Главное преимущество общественной работы женщины видят в том, что теперь и они стали полноправными членами общества, их голоса слышны, и они могут влиять на ситуацию в стране. Работницы одного из московских заводов говорят, что слишком долго выполняли чужие приказы, «через чужие руки глядели», а теперь хотят решать все сами, строить свой мир [52]. Безусловно, здесь мы не говорим о реальной политике и о том, как фактически принимались государственные решения в СССР в 1920-1930-х гг., но лишь о самоощущении женщин, которое было представлено на страницах журнала.

Многие работницы говорят о том, что их жизнь после революции стала интереснее, ярче, насыщеннее. Женщины средних лет признаются, что только сейчас начинают «жить по-настоящему» $[15$, с. 10$]$, и им «хо- чется прожить еще столько же лет» [10, с. 13], сколько уже прожито.

Таким образом, журнал транслирует читателям общий нарратив дореволюционного поколения женщин и подчеркивает те их черты, которые необходимы и юным девушкам Советской страны, на долю которых выпадет строительство молодого коммунистического государства. Редакция подчеркивает, что необходимо быть стойкими, трудолюбивыми, грамотными, быть полезными обществу, стремиться помогать слабым. Основной посыл, транслируемый «Работницей» своим читательницам, заключался в прославлении труда и его радостей. Главным направлением жизни советской женщины стала ее работа на благо своей страны. Начиная с первых номеров журнала, редакция представляет читательницам разные виды профессий и пропагандирует необходимость и важность даже неквалифицированной работы.

В 1920-е гг. «Работница» без прикрас описывает трудную, подчас вредную работу и женщин, выполняющих ее. Например, рассказывая о работе на шахте, корреспондент пишет, что это «тяжелая и грязная работа» [19], на которой к тому же можно получить серьезные травмы, порезать углем ноги или повредить руку при работе на вагонетках. Автор заметки о ткацкой фабрике также беспокоится о здоровье тех женщин, кто работает рядом со спиртовыми и кислотными машинами, поскольку в этом цехе высока заболеваемость туберкулезом [42]. В 1928 г. вышла небольшая заметка о профессиональных заболеваниях ткачих и сложностях этой профессии [58, с. 32]. Но таких статей было немного, а с начала 1930-х гг. они практически исчезают со страниц журнала. После принятия пятилетнего плана и начала индустриализации в журнале стали все меньше писать о трудностях работы. На первый план 
вышла тема радости труда, гордости за выполнение плана, чувство общности с коллективом.

Даже обращая внимание на очевидные трудности производства, авторы статей описывали работниц как веселых, смелых и волевых девушек. Работницы шахт стремятся к знаниям, учатся в школе ликвидации безграмотности, организованной на шахте [19]. Многие вовлечены в общественную жизнь, решают социальные проблемы не только на своем производстве, но и в целом по своему району. Так, свыше 300 торфяниц с торфоразработок в Рязанской губернии стали делегатками женотдела [40, с. 22]. Подобными сообщениями журнал поддерживает в женщинах стремление работать и представляет работающих женщин уверенными в себе и самостоятельными.

Для поддержания образа независимой работницы журнал подчеркивает тот факт, что при многих фабриках и заводах есть свои ясли и детский сад, прачечная, столовая, то есть женщина может полноценно работать, сняв с себя часть хлопот по ведению домашнего хозяйства и присмотру за детьми. Женщина больше не нуждается в помощи старших родственниц или подруг, рассчитывает только на свои силы с учетом тех возможностей, которые предоставляет ей производство.

Еще одним важным моментом в организации самостоятельной жизни является получение работницей достойной заработной платы. Во многих статьях, особенно 1920-х гг, даны подробные цифры о том, сколько женщина зарабатывает на неквалифицированной и квалифицированной работе [46]. «Работница» постулирует, что теперь женщина сама может содержать свою семью и даже позволить себе дорогие покупки. Например, комбайнер Петрова из Саратовского края рассказывает журналу о том, что за лето 1934 г. она смогла заработать «800 руб. деньгами и 10 центнеров хлеба» [43, c. 36], тогда как комбайнеры-мужчины получили меньше, чем она. На эти деньги работница, которая к тому же была участницей совещания передовых комбайнеров в Москве, смогла купить себе много замечательных вещей. Среди покупок она отмечает «велосипед, пальто, шелковый вязаный платок, валенки, отрез на костюм, на платье - купила всего порядочно» [43].

С увеличением собственного благосостояния связана и другая сторона работы на производстве а именно повышение квалификации и получение рабочей специальности. «Работница» призывала женщин не сидеть в одном цехе, выполняя лишь простую механическую неквалифицированную работу, но учиться дальше. Такая возможность у женщин была - на многих заводах были открыты так называемые школы фабрично-заводского ученичества (ФЗУ), в которых рабочие могли осваивать новую специальность на своем рабочем месте. Параллельно с этим среди работниц идет процесс обучения грамоте, женщин учат читать и писать, при заводах созданы школы ликвидации безграмотности (ликбезы), которые посещают как совсем юные, так и взрослые работницы.

В 1925 г. в заметке А. Артюхиной о необходимости учебы звучат привычные для того времени слова о необходимости уметь «управлять государством» и «повышении культурного уровня» работниц [4, с. 3-4]. Осенью того же года журнал печатает в качестве передовицы статью наркома просвещения А.В. Луначарского, в которой он отмечает, что несмотря на существующее в стране равноправие мужчин и женщин, последние все еще «очень неразвиты» и необходимо «поднимать [их] культурный уровень» [31]. Известный советский юрист и автор журнала $\Phi$. Нюрина призывает работниц начать учебу, чтобы бороться с недостатками вокруг себя и несправедливостью на работе. По мнению автора, 
каждая женщина «должна захотеть этому научиться» [38, с. 5]. Однако за общими словами руководителей государства и редакторов журнала стоит и серьезная необходимость - в стране увеличивается количество безработных, неквалифицированных женщин-работниц чаще сокращают, «вновь принимают больше рабочих, чем работниц» [4, с. 3]. Следовательно, женщинам нужно повышать профессиональный уровень, чтобы сохранить свои рабочие места.

Информацию о постоянно растущем уровне безработицы и необходимости получения квалифицированной работы подтверждают и письма в журнал самих работниц. Об этом пишет, например, рабкор из Брянска, сетующая на трудное финансовое положение женщин-рабочих и призывающая «провести серьезную борьбу... за закрепление работниц на производстве» [41], организовать на производстве обучение женщин, чтобы они смогли получить более высокооплачиваемую работу. При этом корреспондентка гордится теми успехами, которые уже есть у работниц предприятия. Некоторые из них обучились новым специальностям и начали работать как «сверловщицы, и на прессах, и у болтореза».

Начиная со второй половины 1920-х гг. в журнале появляется множество оптимистичных статей о работницах, освоивших новое для себя дело и ставших квалифицированными рабочими с более высокой заработной платой. По мнению журналистов, женщины поняли, что современное им производство невозможно без знания техники, без умения работать на станках и разбираться в них. Кроме того, получение квалификации не только делало материальное положение работницы стабильным, но и защищало ее от безработицы $[14$, с. 15]. Судя по письмам в редакцию и заметкам рабкоров, сами женщины также понимали необходимость освоения грамоты и получения рабочей специальности. Работницы швейной фабрики говорили корреспонденту журнала, что стремятся работать лучше, хотят делать меньше брака и понимать технологию производства [2, с. 13]. Работница ленинградского завода «Красный треугольник» признавалась, что хочет «побольше подучиться, чтобы больше принести пользы нашему Союзу и партии» [45].

Помимо экономической стабильности женщины видели в освоении производственной техники и ряд эмоциональных и социальных преимуществ. Изучая сложный механизм, женщина поднимала свою самооценку и могла чувствовать себя равной коллеге-мужчине. $\mathrm{Pa}$ ботницы считали, что «подружились со станком. Он поднимает развитие и обеспечивает прочное положение в производстве» [14]. Кроме того, изучение новой специальности и обучение грамоте делало женщин активными членами общества, они интересовались социальными проблемами, изучали политическое устройство страны, понимали, как можно исправить те или иные недостатки, знали, к кому обратиться за конкретной помощью.

Образование давало возможность женщинам разобраться во внутрисемейных делах, украсить и обустроить свое жилье. По мнению отдельных авторов, женщина-чернорабочая не может быть активной, она беспомощна и в работе, и в быту, и в семейных отношениях, и, только получив техническую специальность, женщина способна «облегчить свой труд и найти возможность перестроить свой быт» [49, с. 4]. Работница Баранова убеждает читательниц стать более активными, уйти от домашнего быта: «Довольно возжаться... с горшками и лоханками, займемся образованием... Просыпайтесь, товарищи работницы...» $[7$, c. 27]. 
«Работница» обращалась также и к тем женщинам, которые потеряли работу, были сокращены с фабрики или завода. Журнал убеждал их не сидеть сложа рука, занимаясь привычными домашними делами, а предлагал найти курсы, чтобы использовать полученные знания, когда работа будет найдена. Кроме того, некоторые курсы предоставляли жилье и питание, что было актуально для неработающих женщин. Также журнал призывал женщин создавать свои артели, совместно ухаживать за детьми, развивать традиционные женские рукоделия [63, с. 32-33].

Итак, тема работы и получения образования - центральная для журнала. «Работница» доказывает своим читательницам необходимость труда для стабилизации их финансового положения и обеспечения независимости. Журнал также ратует за борьбу с неграмотностью и получение более высокой квалификации. Работающая женщина репрезентуется читателю как активная, думающая, уверенная в себе и твердо стоящая на ногах. Такая женщина понимает необходимость образования и повышения своей рабочей квалификации, она независима, может сама упорядочить свою жизнь и быт, воспитать ребенка. При этом работница социально активна, она заботится о своих коллегах, помогает организовать при заводе ясли и детский сад, может быть выбрана делегаткой женотдела и заниматься бытовыми проблемами уже на уровне города или района.

Еще одной важной темой, которой глубоко интересовался журнал и которая также была связана с рабочими отношениями, стала проблема равноправия полов на производстве. Попав в традиционно исключительно мужскую среду, женщине пришлось отвоевывать там свое место и доказывать, что она может работать на равных с мужчиной, что она готова выполнять самую трудную и тяжелую работу. «Работница» всегда поддер- живала стремление женщин к получению необходимой квалификации и их труд на так называемых мужских участках работы. В 1926 г. журнал инициировал дискуссию о том, может ли женщина работать на тяжелых работах. Ее начала статья «Может ли женщина быть слесарем» $[9$, с. 20], в которой слесаря-мужчины обсуждали, могут ли женщины выполнять их работу. Мнения слесарей разделились, большинство из них считало, что женщина не справится с такой технически сложной задачей. В последующих номерах журнала дискуссия продолжилась, были высказаны разные точки зрения, работницы писали в журнал со всей страны. Очевидно, что сам журнал придерживался мнения о том, что женщина готова и может выполнять трудную, тяжелую работу.

В журнале печаталось множество статей, описывающих те трудности, которые преодолевали женщины, стремящиеся выполнять мужскую работу. Уже с началом учебы девушки сталкивались с недоверием к ним молодых ребят, которые были уверены, что учениц прислали, чтобы «шпионить» за ними. Однако девушки быстро понимали технику работы и запоминали необходимые производственные термины. Постепенно ребята и сами начали подсказывать девушкам, как правильно работать с инструментами. «Вначале рубили железо как-то «по-бабьи», потом присмотрелись и ныне рубят «по-заправски», как истые слесаря...» [54, с. 7]. Рабкор Чугунова из Евпатории сетует на то, что администрация школы ФЗУ была против обучения девушекподростков рабочим специальностям токаря и слесаря. При этом и сами девушки не сразу поняли, «какое место они должны занять в производстве», однако постепенно втянулись в работу, и теперь мастера с удивлением отмечают, что девушки успешнее справляются с заданиями, чем юноши [59, с. 9]. Учиться девушкам было трудно, но они осознавали необходимость этого. 
На механическом заводе в Подольске три работницы начали учиться на слесарей и признавались корреспонденту, что учиться им «тяжеловато», но они будут стараться привыкнуть, поскольку им надо «квалификацию поднимать!» [20, с. 11].

Часто ситуация с неприятием женщин-рабочих повторялась и на производстве. На заводе в Сталинграде рабочий на собрании заявил, что «все мужчины будут бороться» против того, что бы женщина встала у станка. По его мнению, «женщин до этого допускать нельзя» $[14$, с. 13]. Клепальщики завода «Красное Сормово» были уверены, что на их участке никогда не будет женщин, но девушки начали выполнять эту работу. Сначала рабочие посмеивались над своими коллегами, но «внимательная, добросовестная работа клепальщиц заставила [их] прикусить языки» [47, с. 15]. Такая же история произошла на ткацкой фабрике «Красная Роза», где молодая женщина впервые начала работать в набивном цеху. Рабочие были уверены, что баба «сразу кишки выпустит», однако девушка отлично справилась с работой [44, с. 19].

О тяжелой работе женщин журнал публиковал не только статьи, но и небольшие литературные эссе. В одном из них повествуется о женщинах, начавших работать в литейном цехе на неквалифицированной работе. Изначально мужчины с недоверием отнеслись к этой затее, не хотели работать рядом с работницами и считали, что те не справятся с тяжелой работой. Однако при поддержке старого рабочего женщины справились с трудностями и начали работать наравне с мужчинами [29].

Не всегда включение в коллектив и начало работы проходило у женщин легко. Комбайнер Петрова в начале своей работы в колхозе не могла сразу сесть за руль трактора - председатель МТС отказывал ей, предлагал другую работу, девушке даже пришлось расплакаться, чтобы добиться своего [43]. На Астраханских промыслах девушку-работницу начали притеснять, переводить с места на место, рабочие-мужчины писали на нее жалобы, а один из них прямо заявил ей, что девушка она хорошая, «но работать не умеет» [61, с. 15]. Работница не отступала, обращалась в партийную ячейку, Госрыбсбыт, просила провести дополнительную ревизию, и в итоге осталась на своем месте. Женщина-шофер из Карагандинской области жалуется, что управляющий автобазы всегда дает ей самую тяжелую и неисправную машину, запрещает обращаться за помощью к другим шоферам, предлагает уволиться, «сидеть дома с горшками» [51, с. 17]. Женщины работали успешно, и мужчины постепенно стали прислушиваться к ним, уважать их мнение, обращаться за помощью. Теперь было не зазорно обратиться к женщине-мастеру, если сломался станок [34, с. 14], или спросить совета у пожилой работницы [13, с. 22].

В журнале выходили также статьи о женщинах-первопроходцах в своих профессиях. В «Работнице» можно прочесть о первых женщинах-вагоновожатых [23], первых контролерах-коммунальщицах [22] и даже большое эссе о девушке-пилоте, которая пришла в авиацию после работы на сборке самолетов [8]. Журнал с завидными упорством и постоянством доказывал обществу, что женщина может выполнять тяжелую работу, убеждал читательниц, что они могут достичь успеха в традиционно мужских специальностях.

По мнению авторов и редакторов «Работницы», героини статей - работающие женщины не только самостоятельны, независимы и грамотны, но и умеют добиваться своего. Несмотря на первые трудности, никто из них не отступил, каждая сумела достичь намеченной цели. Так складывается еще один нарратив, уже моло- 
дого, послереволюционного поколения женщин. Им очевидна необходимость образования, они стремятся работать на крупном предприятии, повышать квалификацию, стать равноправными участниками производственного процесса.

Обычно начало работы у девушек идет трудно, коллеги-мужчины в лучшем случае подшучивают над ними, а иногда прямо противостоят их появлению в цехе и говорят, что у девушек ничего не выйдет, их игнорируют, им не доверяют, пытаются выжить с рабочего места. Иногда в этот момент в рассказе появляется фигура старого рабочего или опытного мастера, который поддерживает девушку, оберегает ее от излишних нападок со стороны мужчин, становится как бы ее проводником и защитником в незнакомом ей мужском мире. Так, например, в одной из статей журнала старый слесарь приводит свою дочь в школу ФЗУ, чтобы научить ее своему ремеслу. Он считает, что хотя это и трудная профессия, девушки должны овладеть ею, чтобы встать за станок вместо старых мастеров. «Пусть по старости заменит меня!» - говорит отец инструктору школы $[1$, с. 14]. Такая поддержка позволяет молодой работнице чувствовать себя уверенно, быстро учиться, внимательно работать, не подводить коллектив, и рабочие принимают ее, начинают уважать и поддерживать.

Очевидно, что подобные истории и их частое повторение в разных вариациях были важны для журнала. Эти рассказы были рассчитаны на молодых девушек, которых можно назвать целевой аудиторией журнала, а значит, перед редакцией стояла задача показать своим читательницам верную модель поведения, научить их не пасовать перед трудностями. Кроме того, молодое советское государство связывало себя именно с молодым населением страны [50, с. 94], а значит, и самому государству необходимы были новые сказки, мифы и герои, и молодая работница становилась таким героем. Интересна фигура пожилого мастера, который помогает девушке. Старый мастер, человек из иного, дореволюционного мира, передает свое дело молодой девушке, очевидно символизирующей молодую советскую страну, сохраняя тем самым связь времен и поколений, оставляя им общую основу для развития.

Эта позиция утверждалась не только в статьях и заметках, но и в стихах и фельетонах. В 1920-е гг. с «Работницей» сотрудничал поэт-сатирик под псевдонимом Архип. Не обошел Архип в своем творчестве и тему равноправия полов на производстве. В небольшом стихотворении представлена уже знакомая нам схема: молодая женщина Варвара стремится работать слесарем к огромному неудовольствию мужчин-рабочих [6, с. 26]. Однако со временем Варя доказала, что отлично справляется со своими обязанностями, и мужчины признают свое поражение:

«И Семен с улыбкой хмурой

Балагурит у станка:

- Вишь, считали бабу дурой,

Мол, кишка у ней тонка.

Не поймет-де ни бельмеса.

Промахнулись мы, гляди,

Образцовый вышел слесарь,

С ней работай, не сиди!»

Интересно, что в номерах начала и середины 1920-х гг. фотографий почти не было, однако с развитием фотографической техники и полиграфии оформлять снимками номер стало проще. Журнал активно использовал на своих страницах фотографии начиная примерно с конца 1920-х гг. Визуальные материалы имеют большое значение для пропагандистских целей. Фото- 
графия или рисунок могут быть более информативными, чем текст, и быстрее донесут до зрителя задуманную автором идею, фотографии не требуют умения читать, а значит, будут поняты большим количеством людей, фотографии более эмоционально заряжены, а значит, получат больше отклика и сопереживания. Кроме того, с современной точки зрения, тексты «Работницы» были довольны слабыми, и фотографии стали «главным носителем пропагандистских функций» $[60$, c. 679].

Уже с первых номеров журнала редакция стала печатать в них портреты передовых работниц или активных делегаток. На этих фото мы видим серьезных хмурых женщин, выглядящих, очевидно, гораздо старше своего настоящего возраста. С началом первой пятилетки посыл фотографических снимков начинает совпадать с текстовой передачей образа работницы. Фотографии могут иллюстрировать статью [21, с. 17; 62], появляются на обложке или целом развороте [39, c. 9-10]. Портретируемые почти всегда молоды, веселы, они улыбаются, они довольны собой и жизнью. Часто на фото для обложки девушки изображены за работой (4/1928; 41/1928; 28/1933). Своего рода визуальным штампом стало изображение девушки, работающей на тяжелом производстве или рядом со сложными станками и приборами (13/1929; 36/1929; 31/1931; 34/ 1931; 38 /1931). Журнал также представлял портреты девушек на учебных занятиях, за чтением (33/1929). Много фотографий снято на праздничной демонстрации $(24 / 1933)$, на прогулке среди подруг (31/1929; 35/1929; 29/1937).

Время от времени на обложках журнала появляются дети $(27 / 1929 ; 29 / 1929 ; 32 / 1931)$, чаще всего, они предоставлены сами себе, играют одни, изредка занимаются под присмотром воспитателя (34/19298). Лишь на одной обложке показаны дети с матерями во время летнего отдыха $(25 / 1929)$. На обложках совсем не представлены мужчины, за исключением лидеров советского государства и военнослужащих на обложках февральских номеров журнала, посвященных Красной Армии и празднованию дня ее создания.

Таким образом, журнал представляет визуальное воплощение образа женщины-рабочей. Это молодая, задорная девушка, которая получает удовольствие и от своей работы, и от отдыха рядом с другими, такими же веселыми юными девушками. Репрезентация женщины-рабочей на производстве занимала основное место среди материалов журнала. Редакторы и корреспонденты убеждали читательниц в том, что работа на благо государства является их основной гражданской обязанностью, а также дает им возможность быть независимыми и самостоятельными. Редакция журнала не использовала поздравительные статьи к Международному женскому дню, чтобы выделить в них женщин-рабочих и их успехи. Образ работницы складывался постепенно с помощью многочисленных статей, писем в редакцию и заметок рабкоров, а также через частушки, фельетоны и сатирические стихи. С началом первой пятилетки особенную важность в журнале приобрели фотографии и рисунки.

Постепенно с помощью журнала также складываются два несхожих нарратива о женской жизни. Один описывает судьбу женщин старшего поколения, их трудную жизнь до революции, второй рассказывает о молодых девушках, которые также должны преодолеть многочисленные трудности на пути к успеху. При этом женщин всех возрастов объединяет активная жизненная позиция, стремление учиться, узнавать новое, много работать, чтобы содержать себя и помогать семье. 
Почти во всех рассказах о женщинах в них нет ничего, кроме работы. Очень редко женщины говорят о своих детях, обычно просто отмечая, что они есть. Мужчины в жизни женщины как бы не присутствуют, а если они и есть, то от них больше проблем, чем помощи. Тем не менее, говоря о репрезентации женщины, нельзя обойти такие важные моменты женской жизни, как семья и материнство. Репрезентация этих и других аспектов жизни, не связанных с производством, станет темой следующей статьи.

\section{Лumepamypa:}

1. А.Д. Будущий токарь // Работница. 1925. № 8. С. 14.

2. А.С. Научимся лучше работать // Работница. 1928. № 37. С. 13.

3. Артюхина А. Как готовиться к 8 марта // Работница. 1925. № 3. С. 1-2.

4. Артюхина А. Работница, образование и квалификация // Работница. 1925. № 6 C. 3-4.

5. Артюхина А. Выполняем постановление ЦК ВКП(б) о 8 марта // 1935. № 10. C. 2-3.

6. Архип. Варюша-слесарь // Работница. 1926. № 18. С. 26.

7. Баранова М. Учиться надо // Работница. 1924. № 19. С. 27.

8. Барсуков Ф. Путь к штурвалу. // Работница. 1925. № 12. С. 17-18.

9. Больщаков. Может ли женщина быть слесарем // Работница. 1926. № 8. С. 20

10. Быкова К. Прошлое и настоящее лысьвенских работниц // Работница. 1935. № 4. С. $12-13$.

11. Бэм С. Линзы гендера: Трансформация взглядов на проблему неравенства полов / Пер. с англ. М.: РОССПЭН, 2004. 336 с.

12. Вавицкая А. К 8 марта провести субботники чистоты // Работница. 1933. № 6. C. 28.

13. Варвара Андреевна Кашурина // Работница. 1924. № 4. С. 22.

14. Васильева Е. К станку // Работница. 1926. № 13. С. 15.

15. Воронцова А.Л. У тверских торфяниц // Работница. 1924. № 21. С. 10.

16. Всколыхнулась сила рабочая // Работница. 1923. № 4. С. 2.

17. Гастев А.К. Наши задачи. Институт труда. URL: http://www.gastev.ru/2015/02/ institut-truda-1921.html (дата обращения 30.08.2019)

18. Герр Е. У работниц Ленских приисков // Работница. 1924. № 19. С. 6.

19. Гирла-Бадаева Л. На Донбассе // Работница. 1924. № 3. С. 21.

20. Гусева А. У работниц механического завода // Работница. 1925. № 2. С. 11.

21. Зайцева. Наказ выполнила // Работница. 1928. № 41. С. 17.
22. И. Первые женщины контролеры // Работница. 1925. № 20. С. 11.

23. Иров. Первые женщины вагоновожатые // Работница. 1924. № 21. С. 19-20.

24. К 8-му марта // Работница. 1923. № 3. С. 21.

25. К международному дню работниц // Работница. 1924. № 4. С. 6-7.

26. К К ъезду советов // Работница. 1924. № 3. С. 15

27. Как они растут // Работница. 1923. № 4. С. 25.

28. Корниенко Н. Чевенгурские мечтания о новом человеке в статьях Платонова 1920-х годов // «Страна философов» Андрея Платонова: проблема творчества. Вып. 6. М.: ИМЛИ РАН, 2005. С. 510-515.

29. Лаврова К. Выдержали // Работница. 1925. № 2. С. 7-8.

30. Ленин Н. Международный день работницы // Работница. 1924. № 4. С. 1-3.

31. Луначарский А.В. Работница и учеба // Работница. 1925. № 19. С. 1.

32. Луначарский А.В. Новый русский человек // Известия ВцИК. 1923. № 53, 9 марта.

33. Международный день работницы // Работница. 1923. № 4. С. 2

34. Может ли женщина быть слесарем. На статью тов. Большакова // Работница. 1926. № 13. С. 14.

35. Николаева К. 8 марта - народный праздник // 1937. № 6-7. С. 3.

36. Николаева К. 8 марта в 1925 году // 1925. № 4. С. 2.

37. Нюрина Ф. 8 марта - пролетарский праздник // Работница. 1928. № 9. С. 3.

38. Нюрина Ф. Работница за учебу // Работница. 1924. № 24. С. 5.

39. Октябрь. 1928. № 40. С. 9-10.

40. Островский Э. У торфяниц // Работница. 1924. № 7. С. 22.

41. Павленко Н. Квалифицируют труд работниц // Работница. 1925. № 8. С. 16.

42. Паэгли А. У работниц ситценабивной фабрики // Работница. 1925. № 10. С. 8.

43. Петрова М. Выполню слово, данное товарищу Сталину // Работница. 1935. № 36. C. 5.

44. П-на. Разбила сказку // Работница. 1928. № 8. С. 19.

45. Получили премии // Работница. 1928. № 8. С. 19.

46. Работница на фабрике // Работница. 1924. № 1. С. 19.

47. Ребуа. Не рассказом, а показом // Работница. 1928. № 40. С. 15.

48. С честью выполняем программу 1-го квартала. // Работница. 1933. № 9. С. 9.

49. Семенова И. Работница и профтехническое образование // Работница. 1924. № 15. С. 4.

50. Смирнова В.Ю. Конструирование возраста в журнале «Работница» в советское время // Женщина в российском обществе. 2016. № 1 (78). С. 94.

51. Сочинская А.П. Вытесняют с производства // Работница. 1937. № 9. С. 17.

52. Среди работниц «Красного богатыря» // Работница. 1924. № 2. С. 14.

53. Ударной работой закрепим итоги 8 марта // Работница. 1933. № 9. С. 2-3.

54. Фабзавучницы // Работница. 1924. № 15. С. 7.

55. Филиппова Е. Об одной крашенной кровати // Работница. 1933. № 7. С. 15.

56. Цеткин К. Привет работницам в день международной солидарности // Работница. 1925. № 4. С. 3. 
57. Цеткин К. Привет русским работницам и крестьянкам // Работница. 1924. № 4. C. 4-5.

58. Чем вреден труд ткачихи // Работница. 1928. № 42. С. 32.

59. Чугунова. Подростки обучаются // Работница. 1925. № 9. С. 9.

60. Шабатура E.А. Образ советской женщины 1920-х годов в журнала «Коммунистка» и «Красная сибирячка» // Гендер и общество в истории. СПб., 2007. С. 679.

61. Ш-на. Девка хороша, да работать не умеешь // Работница. 1928. № 28. С. 15.

62. Щеланова М. Мы создали наше замечательное метро // Работница. 1935. № 7. C. 10-11.

63. Attwood L. Creating the new Soviet woman. Women's Magazines as Engineers of Female Identity, 1922-53. Palgrave Macmillan UK, 1999. 213 p.

\section{Marina Latysheva}

Historian, Master, High school of Economics (Moscow),

mss152204@universitas.ru

\section{The image of a Soviet woman in the «Worker» magazine}

\section{(1923-1937)}

The purpose of this study is to analyze the representation of women-workers in the official Soviet press. As a source, the author chose the magazine «Worker» that is, along with "Peasant», the key women's magazine of the researched period. The duality of woman's position in the Soviet Union, in which she was supposed to be both a worker, social volunteer, and political actor, and at the same time to remain a mother and wife, was reflected in the pages of Soviet women's magazines. The study analyzes how exactly the state rhetoric against women and changes in the government's point of view were reflected in the official press at different times.

Keywords: anthropology of Sovietness, gender studies, «Worker» magazine, Soviet woman, woman at work

\section{ЭКСПЕДИЦИЯ}

\section{Андрей Туторский}

\section{В гостях у православных Уганды}

Автор рассказывает о своей экспедиции в «сердие православной Африки», как называют Уганду сами местные жители, принадлежащие к этой конфессии. Уганда оста ется крупнейшей православной страной Африки, каждый сотый житель этой страны исповедует православие.

Ключевые слова: Уганда, православие в Африке, старообрядиы Уганды, православные школы, миссионерство, история Уганды, Джордж Александр Макгвайр, Рубейн Мукаса, Иринопольская метрополия, Феодор Нанкьяма, общинность

\section{Уганда на карте Африки}

Уганда находится в Восточной части Африки, граничит с Кенией, Танзанией, Руандой, Демократической республикой Конго и Южным Суданом. Это чрезвычайно быстро растущая страна. При приросте населения 33\%о она занимает второе место по этому показателю после другой африканской страны - Малави. Еще более стремительными темпами в стране идет урбанизация населения. Население столицы Кампалы увеличилось с 68000
Туторский Андрей

\section{Владимирович,}

кандидат исторических наук, дочент кафедры этнологии исторического факультета Московского государственного университета

им. М.В. Ломоносова (Москва), tutorski@mail.ru человек в 1948 г. до 1650000 в 2019-м, причем прирост за последний год составил 150000 или 10\%!

Слово Уганда происходит от названия крупнейшего народа - баганда, который составляет более $16 \%$ населения страны. Ба-ганда- это люди ганда, м-ганда - это человек ганда, лу-ганда - 